\title{
Mother Africa, father Marx: women's writing of Mozambique - 1948-2002, de Hilary Owen
}

\author{
MARC SABINE \\ Universidade de Nottingham
}

excelente estudo de Hilary Owen, ${ }^{1}$ o primeiro livro sobre a produção de escritoras moçambicanas a ser editado em língua inglesa, recomenda-se a todos apreciadores das culturas da África lusófona pelo sucesso em realçar, de modo tão incisivo quanto imaginativo, a complexa relação de divisões de género com a concepção da nação e o domínio da palavra literária. Como o significado duplo do seu título indica, o livro propõe não o remodelar do cânone moçambicano para assim outorgar mais destaque à experiência e autoria femininas, mas sim a interrogação, sustentada pela teoria pós-colonial feminista, do conceito de canonicidade em si próprio. Por meio de uma abordagem lúcida, e arguta, Owen evidencia os contornos específicos ao caso moçambicano das relações hierarquizadas de género em que se radicam os discursos sobre a nação e a nacionalidade, e explora a apropriação e a transformação levadas a cabo por quatro autoras dos símbolos e tropos cardeais desses discursos. As leituras meticulosas que Owen oferece de obras-chave de Noémia de Sousa, Lina Magaia, Lília Momplé e Paulina Chiziane reivindica o sucesso destas em desafiar as vagas na narrativa da moçambicanidade que, ao longo da sua evolução desde a época do lusotropicalismo até aquela do neoliberalismo, marginalizaram ou restringiram as liberdades de agência e expressão femininas.

O bom êxito do volume deve-se, antes de mais, à introdução sinóptica que Owen oferece à emergência, nos anos 40 e 50, do discurso de moçambicanidade em oposição à visão integralista do Estado Novo e guiado pelo co-

1. Mother Africa, father Marx: Women's writing of Mozambique - 1948-2002. Lewisburg: Bucknell University Press, 2007. 
munismo e o pan-africanismo. É graças a este delineamento agudo do pano de fundo histórico que a inovadora abordagem teórica que Owen sintetiza se aplica com precisão e clareza. Convocando ideias provenientes de uma diversidade de teoristas, inclusivamente Boaventura de Sousa Santos e Gloria Anzaldúa, Owen propõe emendar a análise de Bhabha, que enfatiza o fenómeno de hibridez e a potência subversiva de estratégias de mimicry. A flexibilidade desta abordagem permite esclarecer não somente as dificuldades, num contexto marcado pelo legado do lusotropicalismo, que moçambicanas encararam em escrever contra ("writing back against") os preceitos e preconceitos eurocêntricos. Também facilita uma investigação, através da literatura, das tentativas de integração de (ou pelo menos, à negociação entre) os conceitos e costumes de género de diversas culturas, dos quais Moçambique moderno é herdeiro. Como Owen indica particularmente na sua leitura da obra de Paulina Chiziane, tais tentativas frequentemente levantaram novos desafios à autodeterminação da mulher.

O ponto de partida do estudo, porém, é a figura imponente da "mãe africana", arquétipo este que, conforme afirma Owen, se encontra produtivamente complexificada tanto no jornalismo como na poesia de Noémia de Sousa. A figura maternal "real e histórica" (p. 47) que se revela susceptível a processos de transição, crise, instabilidade e consciencialização política chega a assumir uma subjectividade muito mais diferenciada do que aquela proporcionada pelo "maternalismo do nacionalismo masculino" (p. 51). O desvio mais audaz do padrão "assimilador e civilizador" (p. 47) encontra-se no poema "Moças das Docas". Aqui, sustém Owen, Noémia integra "identidades sexuais supostamente dissidentes ou "decadentes" num projecto de "narrar a nação em termos de espaço de comunidade não-familiar" (p. 72), e visa "a participação feminina na revolução por vir enquanto algo mais que um simples ponto de desarticulação da política lusotropical” (p. 76).

Ao passar da poesia de Noémia a textos de Lina Magaia, que se conformam menos cabalmente com as definições clássicas de "literatura", Owen reafirma que tanto a escritura jornalística ou popular como a erudida ou canônica tiveram destaque na construção do imaginário nacional, especialmente durante os dolorosos anos do final das décadas de 70 e 80 . Sustetando que o papel social da mulher se manifestou como ponto de contestação fulcral entre uma Frelimo revolucionária e uma Renamo (em grande parte) tradicio- 
nalista, Owen frisa a ilustração, nos contos de Magaia, de como a insurreição de Renamo forçou o reconhecimento das diferenças sexuais e culturais da mulher, anteriormente negadas pela política governamental. O testemunho que Magaia dá ao colapso do projecto Frelimo reconhece que o terrorismo da Renamo visou não apenas a ruína da infra-estrutura do estado marxista, mas também a "alienação" do indivíduo desse estado e da visão comunitária que este propagava. Neste contexto, afirma Owen, os "actos performativos do dia-a-dia" desempenhados pelas protagonistas de Magaia representam-se como "um tipo de heroísmo, comparável àquele dos militares, que restituem a sociabilidade" (p. 115).

Na obra pós-guerra de Lília Momplé e Paulina Chiziane, Owen salienta o reconhecimento da impossibilidade de voltar a um simples apelo a um imaginário nacional integrado e fixo, reconhecimento este que desmente um "foco aparentemente pedagógico" sobre a história do país (p. 130). Adaptando outra vez a posição de Bhabha, Owen traça com destreza a representação da autoalienação colonial através de formulações do unheimlich correspondentes à imbricação das esferas pública e privada. Enquanto "Ninguém Matou Suhura" revisita estratégias e motivos fundamentais do famoso conto de Honwana para alegorizar a operação da mitologia lusotropicalista de ocultar os abusos sexuais, Neighbours adopta uma aproximação mais ambígua ao formato alegórico para culpar as "formas de paternidade ambivalentes, inadequadas, e decepcionantes estabelecidas pelas normas de organização doméstica do colonialismo" (p. 154). Se n'Os olhos da cobra verde também um elemento do unheimlich evidencia a persistência pós-guerra da opressão e agressão coloniais e patriarcais, Momplé não propõe uma resposta mais concreta do que o "imaginar tentativamente eventuais novos espaços domésticos para o futuro" (p. 157).

É nos romances de Paulina Chiziane, no entanto, que Owen identifica a indagação mais profunda da relação dinâmica e mutuamente formativa entre a concepção da nação e as divisões de género. Salienta-se a interrogação, no aspecto (quase-)histórico da ficção de Paulina, das negociações transculturais entre as estruturas patriarcais das culturas Tsonga e de variados discursos de modernidade, e as suas consequências por vezes nefastas no que toca ao status das mulheres. Conforme refere Owen, esta obra distingue-se pela atenção, ao nível de linguagem e estruturação narrativa, ao predomínio masculino no acesso a, e controle sobre, a língua portuguesa. Ao percorrer habilmente di- 
versas intertextualidades orais e escritas, Chiziane chega a reinventar o passado oral, assim atingindo uma 'apropriação do "nome da tradição" (p. 187) que serve para desmascarar o artifício de narrativas de autoridade predicado sobre o mito e o arcaísmo. O potencial da resultante concepção do discurso sobre género enquanto "força dinâmica e estruturante de transformação [social]" (p. 192) é, sobretudo, evidente em Niketche. Nesta genial e burlesca História de Poligamia, as protagonistas empregam estratégias de reinvenção ou ironização de tradições enquanto "bricolage libertadora" para combater as normas sexuais desigualitárias que deturparam a política de integração de uma pluralidade cultural na vida e imaginária da nação moderna.

Concluindo seu estudo com uma breve reflexão sobre a fortuna editorial das obras de Momplé e Chiziane num mercado literário global, Owen debruça-se sobre novas aberturas e novos desafios encarados pelas autoras moçambicanas da actualidade. Embora o discurso da nação pareça "cada vez mais obsoleto" num contexto económico globalizado e neoliberal, Owen afirma, com Hardt e Negri, que a "representação política e literária de interesses e investimentos nacionais" continua a ser imprescindível (p. 42). No reconfigurado ou "pós-moderno" projecto nacional de harmonizar a diversidade interna sem deslizar para uma simples "celebração da 'hibridez' que beneficie os novos senhores do Império global” (p. 221), as contribuições traçadas a partir de pontos de vista femininos - inclusive aquelas aqui apresentadas, elaboradas com tanta perspicácia - não deixam de ser fulcrais.

Recebido em 13 de abril e aprovado em 15 de maio de 2010. 